\title{
Efficacy of some local isolates of the fungus Beauveria bassiana (Balsamo) Vuillemin on the alfalfa weevil Hypera postica (Gyllenhal) (Coleoptera: Curculionidae) larvae, under laboratory conditions
}

\author{
Emine Baysal, Turgut Atay *i] and Yusuf Yanar
}

\begin{abstract}
Control potential of 10 Beauveria bassiana isolates, isolated from Hypera postica (Gyllenhal) (Coleoptera: Curculionidae) and Gonioctena fornicata (Brüggemann) (Coleoptera: Chrysomelidae), collected from alfalfa fields in Tokat province, Turkey, was evaluated against $H$. postica larvae under laboratory conditions. Concentration-response tests were carried out using the concentrations $\left(1 \times 10^{3}, 1 \times 10^{5}, 1 \times 10^{7}\right.$, and $1 \times 10^{9}$ conidia/ml) of isolates GN-23, GN-4, HP-30, and HP-6, which performed more than $95 \%$ efficacy in screening tests $\left(1 \times 10^{7}\right.$ conidia/ml $) 5$ days post treatments. $\mathrm{LT}_{50}$ and $\mathrm{LT}_{90}$ values at $1 \times 10^{9}$ conidia/ml were determined. According to the obtained results, H. postica larvae were susceptible to all the tested B. bassiana isolates.
\end{abstract}

Keywords: Entomopathogenic fungi, Beauveria bassiana, Efficacy, Alfalfa weevil, Larvae, Hypera postica

\section{Background}

Alfalfa (Medicago sativa L.) is one of the well-known and widely used forage crops in the world. Its high yield and quality allows it to be used in feeding programs of different types of livestock (Bates 1998). Alfalfa is attacked by a numerous number of insect species that cause considerable damage and reduce forage yield. Alfalfa weevil Hypera postica (Gyllenhal) (Coleoptera: Curculionidae) is one of the most important pests that attack this crop. Both adults and larvae feed on alfalfa foliage, but the larvae cause the majority of the damage. Larvae feed initially on the inside of terminal leaves and later move to the lower portions of the plant, while adults generally feed on the leaf margins. Injured leaves dry very quickly giving the field a grayish to whitish cast. This pest can be found in all alfalfa production areas of Turkey and worldwide (Cook et al. 2004 and Atanasova 2012).

\footnotetext{
* Correspondence: turgut.atay@gop.edu.tr

Department of Plant Protection, Faculty of Agriculture, Gaziosmanpasa University, Tokat, Turkey
}

Frequent cuttings are the most effective cultural method of the pest in the alfalfa fields. Chemical control can be recommended, if there are 25 adults in $1-\mathrm{m}^{2}$ area before the first mowing (Erdoğan 2008). However, the chemical insecticides used to manage this pest are extremely hazardous to bees and other beneficial insects (Reddy et al. 2016). Some efficient biological control agents, particularly entomopathogenic fungi (EPF), and some hymenopteran parasitoids have been recorded (Atay et al. 2015; Reddy et al. 2016; Efil 2018 and Yücel et al. 2018).

The application of EPF in bio-control of insects is of immense significance because of their environmental and food safety concerns (Reddy et al. 2016). Species of the genera Beauveria, Metarhizium, Lecanicillium and Isaria are commercially produced (Vega et al. 2009). B. bassiana was reported to infect 707 species of insect hosts, including 521 genera and 149 families of 15 orders (Imoulan et al. 2017). Some studies have been conducted to determine the potential of $B$. bassiana as a bio-agent against various insect pests in Turkey. These studies 
have mostly focused on lepidopteran and coleopteran pests (Güven et al. 2015; Yanar et al. 2017).

There are several studies concerning biological control of H. postica by EPF in Turkey (Atay et al. 2015 and Yücel et al. 2018) and in the world (Hedlund and Pass 1968; Roberts et al. 1994; Mustafa et al. 2014 and Reddy et al. 2016).

The objective of this study was to determine the efficacy of 10 local B. bassiana isolates, isolated from $H$. postica and Gonioctena fornicata, collected from alfalfa fields in Tokat province, Turkey, against larvae of the alfalfa weevil under laboratory conditions.

\section{Methods}

\section{Isolation of fungi}

Overwintered adults of $H$. postica and G. fornicata emerged from the soil were collected from alfalfa fields of Tokat, Turkey, during the period, April-May 2015 (Table 1). The collections were brought to the laboratory with fresh alfalfa plants, transferred to separate cages and checked daily. The dead adults were subjected to surface sterilization with $1 \%$ sodium hypochlorite solution for $1 \mathrm{~min}$, washed twice with distilled water, placed in a sterile Petri-dish containing moistened filter paper and kept at $25 \pm 2{ }^{\circ} \mathrm{C}$ and 16L: 8D h photoperiod (Ali-Shtayeh et al. 2002). By the end of incubation period, the fungus was isolated from the adults, with external fungal growth, with special care (Sevim 2010). PDAY (PDA $+1 \%$ yeast extract)

Table 1 Hosts and locations of the tested enthomopathogenic Beauveria bassiana isolates

\begin{tabular}{|c|c|c|c|c|c|}
\hline \multirow[t]{3}{*}{ Isolates } & \multicolumn{4}{|c|}{ Information of Locations } & \multirow[t]{3}{*}{ Hosts } \\
\hline & \multirow[t]{2}{*}{ Location } & \multicolumn{2}{|c|}{ Coordinates } & \multirow{2}{*}{$\begin{array}{l}\text { Altitude } \\
\text { (m) }\end{array}$} & \\
\hline & & $\mathrm{N}$ & $E$ & & \\
\hline$\overline{G N-23}$ & $\begin{array}{l}\text { Gümenek, } \\
\text { Tokat, Turkey }\end{array}$ & $\begin{array}{l}40^{\circ} 21^{\prime} \\
56^{\prime \prime}\end{array}$ & $36^{\circ} 38^{\prime} 39^{\prime \prime}$ & 637 & $\begin{array}{l}G . \\
\text { fornicata }\end{array}$ \\
\hline GN-20-2 & $\begin{array}{l}\text { Yağmurlu, } \\
\text { Tokat, Turkey }\end{array}$ & $\begin{array}{l}40^{\circ} 30^{\prime} \\
51^{\prime \prime}\end{array}$ & $36^{\circ} 49^{\prime} 17^{\prime \prime}$ & 829 & $\begin{array}{l}\text { G. } \\
\text { fornicata }\end{array}$ \\
\hline GN-12-3 & $\begin{array}{l}\text { Emirseyit, } \\
\text { Tokat, Turkey }\end{array}$ & $\begin{array}{l}40^{\circ} 20^{\prime} \\
16^{\prime \prime}\end{array}$ & $36^{\circ} 24^{\prime} 21^{\prime \prime}$ & 572 & $\begin{array}{l}\text { G. } \\
\text { fornicata }\end{array}$ \\
\hline $\mathrm{GN}-1$ & $\begin{array}{l}\text { Ulaş, Tokat, } \\
\text { Turkey }\end{array}$ & $\begin{array}{l}40^{\circ} 19^{\prime} \\
18^{\prime \prime}\end{array}$ & $36^{\circ} 26^{\prime} 12^{\prime \prime}$ & 600 & $\begin{array}{l}\text { G. } \\
\text { fornicata }\end{array}$ \\
\hline GN-4 & $\begin{array}{l}\text { Gürylldız, } \\
\text { Tokat, Turkey }\end{array}$ & $\begin{array}{l}40^{\circ} 19^{\prime} \\
58^{\prime \prime}\end{array}$ & $36^{\circ} 22^{\prime} 35^{\prime \prime}$ & 582 & $\begin{array}{l}\text { G. } \\
\text { fornicata }\end{array}$ \\
\hline GN5-2 & $\begin{array}{l}\text { Güryldız, } \\
\text { Tokat, Turkey }\end{array}$ & $\begin{array}{l}40^{\circ} 19^{\prime} \\
49^{\prime \prime}\end{array}$ & $36^{\circ} 22^{\prime} 04^{\prime \prime}$ & 525 & $\begin{array}{l}\text { G. } \\
\text { fornicata }\end{array}$ \\
\hline GN8-2 & $\begin{array}{l}\text { Büyükyıldız, } \\
\text { Tokat, Turkey }\end{array}$ & $\begin{array}{l}40^{\circ} 20^{\prime} \\
12^{\prime \prime}\end{array}$ & $36^{\circ} 23^{\prime} 37^{\prime \prime}$ & 567 & $\begin{array}{l}\text { G. } \\
\text { fornicata }\end{array}$ \\
\hline $\begin{array}{l}\text { GN-8- } \\
1(2)\end{array}$ & $\begin{array}{l}\text { Büyükyıldız, } \\
\text { Tokat, Turkey }\end{array}$ & $\begin{array}{l}40^{\circ} 20^{\prime} \\
12^{\prime \prime}\end{array}$ & $36^{\circ} 23^{\prime} 37^{\prime \prime}$ & 567 & $\begin{array}{l}\text { G. } \\
\text { fornicata }\end{array}$ \\
\hline HP-30 & $\begin{array}{l}\text { Bedirkale, } \\
\text { Tokat, Turkey }\end{array}$ & $\begin{array}{l}40^{\circ} 03^{\prime} \\
56^{\prime \prime}\end{array}$ & $36^{\circ} 26^{\prime} 48$ & 1133 & H. postica \\
\hline HP-6 & $\begin{array}{l}\text { Güryıldız, } \\
\text { Tokat, Turkey }\end{array}$ & $\begin{array}{l}40^{\circ} 19^{\prime} \\
45^{\prime \prime}\end{array}$ & $36^{\circ} 21^{\prime} 40^{\prime \prime}$ & 585 & H. postica \\
\hline
\end{tabular}

media were used for isolation. To prevent bacterial contamination, $50 \mu \mathrm{g} / \mathrm{ml}$ ampicillin, $20 \mu \mathrm{g} / \mathrm{ml}$ tetracycline, and $200 \mu \mathrm{g} / \mathrm{ml}$ streptomycin were added to the medium (Ihara et al. 2001). Single-spore isolates of all the isolates were obtained by serial dilution (Dhingra and Sinclair 1995) and were identified as B. bassiana. Totally, ten $B$. bassiana isolates were isolated from the field-collections of H. postica and G. fornicata adults (Table 1), and they were deposited in the fungal culture collection of the Mycology Laboratory at the Gaziosmanpasa University, Faculty of Agriculture, Department of Plant Protection in Tokat, Turkey. In order to obtain sufficient amounts of spore suspensions, the fungi were sub-cultured in PDA (Potato Dextrose Agar) medium. The fungi cultures were incubated at $25 \pm 2{ }^{\circ} \mathrm{C}$ for 17 days. Ten milliliters of sterilized water with $0.02 \%$ Tween 80 was added to each plate, and spore harvesting was done by gently rubbing the culture surface, using a sterilized glass hokey. Spore suspension from each isolate was adjusted to $1 \times 10^{3}, 1 \times 10^{5}, 1 \times$ $10^{7}$, and $1 \times 10^{9}$ conidia/ml (Şahin 2006).

\section{Bioassays}

Primarily, screening tests were conducted to determine the efficacy of the isolates against $H$. postica larvae at $1 \times 10^{7}$ conidia $/ \mathrm{ml}$. To test the effect of each isolate, $H$. postica

Table 2 Mortality of Hypera postica exposed to the ten isolates at $1 \times 10^{7}$ conidia/ml

\begin{tabular}{|c|c|c|c|c|}
\hline \multicolumn{5}{|c|}{ Mortality $\pm S E M^{*}(\%)$} \\
\hline ISOLATES & $1 \mathrm{DAT}^{* *}$ & 3 DAT & 5 DAT & 7 DAT \\
\hline GN-23 & $\begin{array}{l}0.29 \pm \\
0.70 a^{* * *}\end{array}$ & $24.83 \pm 0.16 c$ & $98.85 \pm 1.12 \mathrm{abc}$ & $\begin{array}{l}100.00 \pm \\
0.00 \mathrm{a}\end{array}$ \\
\hline GN-20-2 & $0.29 \pm 0.70 a$ & $\begin{array}{l}60.22 \pm \\
0.52 \mathrm{ab}\end{array}$ & $\begin{array}{l}94.43 \pm \\
1.49 \mathrm{abcd}\end{array}$ & $99.71 \pm 0.70 a$ \\
\hline GN-12-3 & $0.00 \pm 0.00 a$ & $\begin{array}{l}51.82 \pm \\
0.92 \mathrm{ab}\end{array}$ & $85.66 \pm 0.49 d$ & $\begin{array}{l}100.00 \pm \\
0.00 a\end{array}$ \\
\hline GN-1 & $0.60 \pm 1.45 a$ & $\begin{array}{l}39.79 \pm \\
0.68 b c\end{array}$ & $86.99 \pm 0.22 \mathrm{~cd}$ & $99.71 \pm 0.70 a$ \\
\hline $\mathrm{GN}-4$ & $2.57 \pm 1.25 a$ & $\begin{array}{l}56.84 \pm \\
0.62 \mathrm{ab}\end{array}$ & $\begin{array}{l}97.43 \pm \\
1.25 \mathrm{abcd}\end{array}$ & $99.71 \pm 0.70 a$ \\
\hline GN-5-2 & $0.29 \pm 0.70 a$ & $\begin{array}{l}53.50 \pm \\
0.79 a b\end{array}$ & $83.64 \pm 0.22 d$ & $\begin{array}{l}100.00 \pm \\
0.00 \mathrm{a}\end{array}$ \\
\hline GN-8-2 & $2.57 \pm 1.25 a$ & $\begin{array}{l}60.22 \pm \\
0.52 \mathrm{ab}\end{array}$ & $88.54 \pm 0.14 b c d$ & $99.71 \pm 0.70 a$ \\
\hline GN-8-1(2) & $2.57 \pm 1.25 a$ & $65.50 \pm 0.72 a$ & $85.36 \pm 0.25 d$ & $\begin{array}{l}100.00 \pm \\
0.00 a\end{array}$ \\
\hline $\mathrm{HP}-30$ & $1.70 \pm 1.74 a$ & $\begin{array}{l}60.22 \pm \\
0.52 \mathrm{ab}\end{array}$ & $99.40 \pm 1.45 a b$ & $\begin{array}{l}100.00 \pm \\
0.00 a\end{array}$ \\
\hline HP-6 & $4.53 \pm 1.12 a$ & $68.72 \pm 0.48 a$ & $99.71 \pm 0.70 a$ & $\begin{array}{l}100.00 \pm \\
0.00 a\end{array}$ \\
\hline CONTROL & $0.00 \pm 0.00 a$ & $0.00 \pm 0.00 d$ & $1.15 \pm 1.12 \mathrm{e}$ & $13.01 \pm 0.22 b$ \\
\hline
\end{tabular}


Table 3 Mortality of Hypera postica exposed to GN-23 isolate

\begin{tabular}{|c|c|c|c|c|}
\hline \multicolumn{5}{|c|}{ Mortality $\pm \mathrm{SEM}^{*}(\%)$} \\
\hline $\begin{array}{l}\text { Doses (conidia/ } \\
\mathrm{ml} \text { ) }\end{array}$ & $1 \mathrm{DAT}^{* *}$ & 3 DAT & 5 DAT & 7 DAT \\
\hline $1 \times 10^{3}$ & $\begin{array}{l}1.65 \pm \\
1.25 a^{* * *}\end{array}$ & $\begin{array}{l}13.66 \pm \\
0.25 b\end{array}$ & $\begin{array}{l}70.95 \pm \\
1.10 \mathrm{~b}\end{array}$ & $\begin{array}{l}86.70 \pm \\
0.54 b\end{array}$ \\
\hline $1 \times 10^{5}$ & $0.29 \pm 0.70 a$ & $\begin{array}{l}20.86 \pm \\
0.65 b\end{array}$ & $\begin{array}{l}82.19 \pm \\
0.40 \mathrm{~b}\end{array}$ & $\begin{array}{l}99.71 \pm \\
0.70 \mathrm{a}\end{array}$ \\
\hline $1 \times 10^{7}$ & $0.29 \pm 0.70 a$ & $\begin{array}{l}24.83 \pm \\
0.16 b\end{array}$ & $\begin{array}{l}98.85 \pm \\
1.12 a\end{array}$ & $\begin{array}{l}100.00 \pm \\
0.00 \mathrm{a}\end{array}$ \\
\hline $1 \times 10^{9}$ & $0.60 \pm 1.45 a$ & $\begin{array}{l}48.58 \pm \\
1.49 a\end{array}$ & $\begin{array}{l}98.85 \pm \\
1.12 a\end{array}$ & $\begin{array}{l}99.71 \pm \\
0.70 a\end{array}$ \\
\hline Control & $0.00 \pm 0.00 a$ & $0.00 \pm 0.00 c$ & $1.15 \pm 1.12 c$ & $\begin{array}{l}13.01 \pm \\
0.22 c\end{array}$ \\
\hline
\end{tabular}

*SEM Standard error of the mean

**DAT Days after treatment

***Means in a column followed by the same letter are not statistical

significantly different $(P<0.05)$

larvae were dipped into conidial suspension of $1 \times 10^{7}$ conidia/ml of each isolate for 4-5 s and placed in a Petri-dish (10 larvae per dish) containing fresh alfalfa leaves. Mortality rates were recorded on the 1 st, 3rd, 5th, and 7 th days post treatment. In addition, concentration-response tests were carried out with isolates proved to have a high effect, using such tested concentrations. The experiments were carried out in completely randomized block design, with three replications and replicated two times.

\section{Statistical analysis}

Test results were converted into percentages and arcsine transformed. The transformed data was analyzed by analysis of variance (ANOVA) and the means compared by Tukey's multiple comparison tests. All statistical analyses were carried out using the MINITAB Release 16 packet program. $\mathrm{LT}_{50}$ and $\mathrm{LT}_{90}$ values of the concentration causing the fastest effect were determined, using the probit analysis.

Table 4 Mortality of Hypera postica exposed to GN-4 isolate

\begin{tabular}{lllll}
\hline Mortality \pm SEM $^{*}(\%)$ & & & \\
\hline $\begin{array}{llll}\text { Doses(conidia/ } \\
\mathrm{ml})\end{array}$ & $1 \mathrm{DAT}^{* *}$ & $3 \mathrm{DAT}$ & $5 \mathrm{DAT}$ & 7 DAT \\
\hline $1 \times 10^{3}$ & $1.15 \pm$ & $28.24 \pm$ & $77.18 \pm$ & $96.63 \pm$ \\
& $1.12 \mathrm{a}^{* * *}$ & $0.09 \mathrm{~b}$ & $0.43 \mathrm{~b}$ & $1.75 \mathrm{a}$ \\
$1 \times 10^{5}$ & $1.15 \pm 1.12 \mathrm{a}$ & $41.43 \pm$ & $80.69 \pm$ & $99.71 \pm$ \\
& & $0.75 \mathrm{ab}$ & $0.54 \mathrm{~b}$ & $0.70 \mathrm{a}$ \\
$1 \times 10^{7}$ & $2.57 \pm 1.25 \mathrm{a}$ & $56.84 \pm$ & $97.43 \pm$ & $99.71 \pm$ \\
& & $0.62 \mathrm{a}$ & $1.25 \mathrm{a}$ & $0.70 \mathrm{a}$ \\
$1 \times 10^{9}$ & $0.00 \pm 0.00 \mathrm{a}$ & $50.00 \pm$ & $98.35 \pm$ & $100.00 \pm$ \\
& & $0.21 \mathrm{a}$ & $1.25 \mathrm{a}$ & $0.00 \mathrm{a}$ \\
Control & $0.00 \pm 0.00 \mathrm{a}$ & $0.00 \pm 0.00 \mathrm{c}$ & $1.15 \pm$ & $13.01 \pm$ \\
& & & $1.12 \mathrm{c}$ & $0.22 \mathrm{~b}$
\end{tabular}

*SEM Standard error of the mean

**DAT Days after treatment

***Means in a column followed by the same letter are not statistical significantly different $(P<0.05)$
Table 5 Mortality of Hypera postica exposed to Hp-30 isolate

\begin{tabular}{|c|c|c|c|c|}
\hline \multicolumn{5}{|c|}{ Mortality \pm SEM* $(\%)$} \\
\hline $\begin{array}{l}\text { Doses(conidia/ } \\
\text { ml) }\end{array}$ & $1 \mathrm{DAT}^{* *}$ & 3 DAT & 5 DAT & 7 DAT \\
\hline $1 \times 10^{3}$ & $\begin{array}{l}0.41 \pm \\
0.84 a^{* * *}\end{array}$ & $\begin{array}{l}62.22 \pm \\
0.52 \mathrm{a}\end{array}$ & $\begin{array}{l}78.11 \pm \\
0.11 b\end{array}$ & $\begin{array}{l}94.13 \pm \\
2.44 a\end{array}$ \\
\hline $1 \times 10^{5}$ & $0.00 \pm 0.00 a$ & $\begin{array}{l}56.03 \pm \\
0.12 a\end{array}$ & $\begin{array}{l}80.82 \pm \\
0.68 b\end{array}$ & $\begin{array}{l}95.18 \pm \\
1.78 a\end{array}$ \\
\hline $1 \times 10^{7}$ & $1.70 \pm 1.74 a$ & $\begin{array}{l}60.22 \pm \\
0.52 a\end{array}$ & $\begin{array}{l}99.40 \pm \\
1.45 a\end{array}$ & $\begin{array}{l}100.00 \pm \\
0.00 a\end{array}$ \\
\hline $1 \times 10^{9}$ & $0.00 \pm 0.00 a$ & $\begin{array}{l}66.92 \pm \\
0.33 a\end{array}$ & $\begin{array}{l}100.00 \pm \\
0.00 a\end{array}$ & $\begin{array}{l}100.00 \pm \\
0.00 a\end{array}$ \\
\hline Control & $0.00 \pm 0.00 a$ & $\begin{array}{l}0.00 \pm \\
0.00 b\end{array}$ & $1.15 \pm 1.12 \mathrm{c}$ & $\begin{array}{l}13.01 \pm \\
0.22 c\end{array}$ \\
\hline
\end{tabular}

*SEM Standard error of the mean

**DAT Days after treatment

***Means in a column followed by the same letter are not statistical significantly different $(P<0.05)$

\section{Results and discussion}

The ten EPF isolates tested against $H$. postica at $1 \times$ $10^{7}$ conidia/ml caused $100 \%$ mortality 7 days post treatment in almost all isolates (Table 2). Concentration-response tests, carried out using concentrations of $1 \times 10^{3}$, $1 \times 10^{5}, 1 \times 10^{7}$, and $1 \times 10^{9}$ conidia/ml of the isolates (GN-23, GN-4, HP-30, HP-6), caused more than 95\% mortality rate on the 5 th day.

The mortality rates of $H$. postica larvae varied from 13.66 to $72.08 \% 3$ days post treatment. The highest mortality rate $(72.08 \%)$ was recorded for HP-6 at $1 \times$ $10^{9}$ conidia/ml (Table 6). HP-30 was the most effective isolate with mortality rate of $62.22 \%$ at $1 \times 10^{3}$ conidia/ml (Table 5). On the 5th day, all isolates and concentrations caused more than $70 \%$ mortality, while on the 7 th day the mortality rate reached $100 \%$ by almost all isolates at $1 \times 10^{7}$ and $1 \times 10^{9}$ conidia $/ \mathrm{ml}$ (Tables 3, 4, 5, and 6).

Table 6 Mortality of Hypera postica exposed to Hp-6 isolate

\begin{tabular}{lllll}
\hline Mortality \pm SEM $^{*}(\%)$ & & & \\
\hline $\begin{array}{l}\text { Doses(conidia/ } \\
\mathrm{ml})\end{array}$ & $1 \mathrm{DAT}^{* *}$ & $3 \mathrm{DAT}$ & $5 \mathrm{DAT}$ & 7 DAT \\
\hline $1 \times 10^{3}$ & $0.41 \pm$ & $52.01 \pm$ & $86.34 \pm$ & $99.59 \pm$ \\
& $0.84 \mathrm{ab}{ }^{* * *}$ & $0.49 \mathrm{~b}$ & $0.25 \mathrm{~b}$ & $0.84 \mathrm{a}$ \\
& $0.00 \pm 0.00 \mathrm{~b}$ & $59.68 \pm$ & $86.99 \pm$ & $97.43 \pm$ \\
$1 \times 10^{5}$ & & $0.34 \mathrm{ab}$ & $0.22 \mathrm{~b}$ & $1.25 \mathrm{a}$ \\
& $4.53 \pm 1.12 \mathrm{a}$ & $68.72 \pm$ & $99.71 \pm$ & $100.00 \pm$ \\
$1 \times 10^{7}$ & & $0.48 \mathrm{a}$ & $0.70 \mathrm{a}$ & $0.00 \mathrm{a}$ \\
& $2.57 \pm 1.25 \mathrm{ab}$ & $72.08 \pm$ & $100.00 \pm$ & $100.00 \pm$ \\
$1 \times 10^{9}$ & & $0.48 \mathrm{a}$ & $0.00 \mathrm{a}$ & $0.00 \mathrm{a}$ \\
& $0.00 \pm 0.00 \mathrm{~b}$ & $0.00 \pm 0.00 \mathrm{c}$ & $1.15 \pm 1.12 \mathrm{c}$ & $13.01 \pm$ \\
Control & & & & $0.22 \mathrm{~b}$ \\
& & & & \\
\hline
\end{tabular}

*SEM Standard error of the mean

**DAT Days after treatment

***Means in a column followed by the same letter are not statistical significantly different $(P<0.05)$ 
Table 7 Lethal time $\left(L T_{50}\right.$ and $\left.L T_{90}\right)$ values of the entomopathogenic fungi, Beauveria bassiana isolates (day)

\begin{tabular}{lllll}
\hline Isolates & Slope $\pm \mathrm{SE}$ & $\begin{array}{l}\mathrm{LT}_{50} \text { (95\% fiducial } \\
\text { limit) }\end{array}$ & $\begin{array}{l}\mathrm{LT} \text { (90 (95\% fiducial } \\
\text { limit) }\end{array}$ & $x^{2}$ \\
\hline GN-4 & $1.040 \pm 0.148$ & $3.110(2.808-3.404)$ & $4.343(3.977-4.907)$ & 7.4 \\
GN-23 & $0.984 \pm 0.122$ & $3.074(2.796-3.350)$ & $4.376(4.024-4.890)$ & 15.7 \\
HP-6 & $1.132 \pm 0.151$ & $2.476(2.215-2.735)$ & $3.608(3.283-4.097)$ & 5.9 \\
HP-30 & $0.174 \pm 0.167$ & $2.401(1.348-2.885)$ & $4.196(3.768-5.014)$ & 5.8 \\
\hline
\end{tabular}

$\mathrm{LT}_{50}$ for HP-30 was 2.401 days, followed by HP-6 (2.476 days), GN-23 (3.074 days), and GN-4 (3.110 days). $\mathrm{LT}_{90}$ values for the isolates of HP-6, HP-30, GN-4, and GN-23 were $3.608,4.196,4.343$, and 4.376 days, respectively (Table 7).

Yücel et al. (2018) tested 7 isolates of B. bassiana and one isolate of $B$. pseudobassiana, isolated from $H$. postica, on larvae and adults of $H$. postica at $1 \times 10^{5}, 1 \times 10^{6} 1 \times$ $10^{7}$, and $1 \times 10^{8}$ conidia/ml. The results showed that the highest mortality rate in larvae was obtained by the isolate HpA-5 (B. bassiana) (100\%) and HpI-4 (B. pseudobassiana) (97\%), within 14 days at $1 \times 10^{8}$ conidia/ml. The highest mortality rate of adults were obtained by the isolates HpA-5 (B. bassiana) and HpI-4 (B. pseudobassiana) with 98 and $95 \%$ mortality rates within 14 days at $1 \times 10^{8}$ concentration, respectively.

Mustafa et al. (2014) reported that conidial suspension with $1 \times 10^{7}$ conidia/ml of two isolates of $B$. bassiana caused $100 \%$ mortality on adults of $H$. postica, 6 days post treatments. Also, Reddy et al. (2016) investigated the efficiency of six biorational-insecticides against $H$. postica larvae under laboratory conditions and found that $\mathrm{Mycotrol}^{\circ}$ ESO (B. bassiana GHA) lasted 5-9 days to kill $100 \%$ of $H$. postica larvae in all the tested concentrations $(0.072,0.36$, 0.72 , and $1.44 \mathrm{ml} / \mathrm{l}$ ). In addition, Atay et al. (2015) stated that $23.25 \%$ of $H$. postica adults, overwintered in alfalfa growing areas of Tokat province in Turkey, were found naturally infected with Beauveria spp. Harcourt et al. (1977) reported that larvae of this pest were found infected with Entomophthora phytonomi Arthur, which considerably reduced the weevil population in Canada.

\section{Conclusions}

The present study showed that the local isolates of $B$. bassiana could be suggested as bio-control agent against $H$. postica larvae; however, further studies should be conducted under field conditions.

\section{Funding}

The study was supported by Gaziosmanpaşa University Scientific Research Fund (project number: 2015/138).

\section{Availability of data and materials}

The dataset(s) supporting the conclusions of this article is(are) included within the article (and its additional file(s)).

\section{Authors' contributions}

The whole team jointly planned the experiments. All authors read and approved the final manuscript.

Ethics approval and consent to participate

Not applicable

\section{Consent for publication}

Not applicable

\section{Competing interests}

The authors declare that they have no competing interests.

\section{Publisher's Note}

Springer Nature remains neutral with regard to jurisdictional claims in published maps and institutional affiliations.

Received: 4 May 2018 Accepted: 19 July 2018

Published online: 07 August 2018

\section{References}

Ali-Shtayeh MS, Abdel-Basit M, Jamous R (2002) Distribution, occurrence and characterization of entomopathogenic fungi in agricultural soil in the Palestinian area. Mycopathologia 156:235-244

Atanasova D (2012) Investigation on the pests and their entomophagous insects in multifoliolate alfalfa (Medicago sativa L.), Plovdiv, PhD thesis

Atay T, Yanar Y, Baysal E, Kepenekci I (2015) Occurrence of entomopathogenic fungus Beauveria sp. on overwintered adults of Hypera postica (Gyllenhal) (Coleoptera, Curculionidae) and Gonioctena fornicata (Brüggemann) (Coleoptera, Chrysomelidae) in soil. 5th Enthomopathogens and Microbial Control Congress. 09-11 September, Ankara, p 82

Bates GE (1998) Alfalfa: high-quality forage production. SP434-C. The Univ.of Tennesee Ext, Knoxville https://extension.tennessee.edu/publications/ Documents/sp434c.pdf. Accessed 20 Apr 2018

Cook KA, Ratcliffe ST, Grey ME, Steffey KL (2004) Alfalfa Weevil. https://ipm.lllinois. edu/fieldcrops/insects/alfalfa_weevil.pdf. Accessed 08 Apr 2018

Dhingra OD, Sinclair JB (1995) Basic plant pathology methods, 2nd edn. CRC Press, Boca Raton

Efil L (2018) The damage status of Alfalfa Weevil Hypera variabilis (Herbst, 1795) (Coleoptera: Curculionidae) in the alfalfa areas of Diyarbakır, Şanlıurfa, Mardin provinces and parasitoid Bathyplectes curculionis (Thomson, 1887) and parazitization. Turkish J Agric Nat Sci 5:86-89

Erdoğan P (2008) Pests of vegetables and feed crops and their control methods. Tarla Bitkileri Merkez Araşırma Enstitüsü Dergisi 15:1-10

Güven Ö, Çayır D, Baydar R, Karaca I (2015) The effects of entomopathogenic fungus Beauveria bassiana (Bals.) Vuill isolates on Colorado potato beetle, [Leptinotarsa decemlineata Say. (Coleoptera: Chrysomelidae)]. Turkish J Biol Control 6:105-114

Harcourt DG, Guppy JC, Binns MR (1977) The analysis of intrageneration change in eastern Ontario populations of the Alfalfa Weevil, Hypera posiica (Coleoptera: Curculionidae). CanEntomol 109:1521-1534

Hedlund RC, Pass BC (1968) Infection of the Alfalfa Weevil, Hypera postica, by the Fungus Beauveria bassiana. J Invertebr Pathol 11:25-34

Ihara F, Yaginuma K, Kobayashi N, Mishiro K, Sato T (2001) Screening of entomopathogenic fungi against the Brown-winged green bug, Plautia stali (Scott), (Hemiptera: Pentatomidae). Appl Entomol Zool 36:495-500

Imoulan A, Hussain M, Kirk PM, El Meziane A, Yao YJ (2017) Entomopathogenic fungus Beauveria: host specificity, ecology and significance of morphomolecular characterization in accurate taxonomic classification. J Asia Pac Entomol 20:1204-1212

Mustafa RA, Assaf LH, Abdullah SK (2014) Comparative pathogenicity of Beauveria bassiana, Clonostachys rosea, Metarhizium anisopliae, and Lecanicillium lecanii to adult, alfalfa weevil Hypera postica Gyllenhal (Coleoptera:Curculionidae). 3rd International Conference on Applied Life Sciences (ICALS2014), Malaysia, pp 1-14

Reddy GVP, Antwi FB, Shrestha G, Kuriwada T (2016) Evaluation of toxicity of biorational insecticides against larvae of the alfalfa weevil. Toxicol Rep 3:473-480

Roberts SJ, Maddox JV, Armbrust EJ (1994) A laboratory infection of Alfalfa Weevil, Hypera postica (Coleoptera: Curculionidae), larvae with the fungal pathogen Zoophthora phytonomi (Zygomycetes: Entomophthoraceae). Great Lakes Entomol 27:19-21 
Şahin H (2006) Çam Kesetıtıı (Thaumetopoea pityocampa (Den\&Schiff)) (Lepidoptera: Thaumetopoeidae)'na karșı farklı entomopatojen fungus izolatlarının etkinliklerinin araştıııması. Fen Bilimleri Enstitüsü, (Yüksek Lisans Tezi), pp 12-15

Sevim A (2010) Doğu Karadeniz Bölgesi'nden entomopatojenik fungusların izolasyonu, Karakterizasyonu ve Virülanslarının Belirlenmesi, Fen Bilimleri Enstitüsü Biyoloji Anabilimdalı, (Doktora tezi), Trabzon, pp 31-32

Vega FE, Goettel MS, Blackwell M, Chandler D, Jackson MA, Keller S, Koike M, Maniania NK, Monzo'N A, Ownley BH, Pell JK, DEN R, Roy HE (2009) Fungal entomopathogens: new insights on their ecology. Fungalecology 2:149-159

Yanar Y, Yanar D, Atay T, Çankaya M, Baysal E (2017) Effects of entomopathogenic fungi Beauveria bassiana isolates on Colarado potato beetle [Leptinotarsa decemlineata (Say)] (Coleoptera: Chrysomelidae). 6th Entomopathogens and microbial control congress, Tokat, p 39

Yücel B, Gözzuaçık C, Gencer D, Demir I, Demirbağ Z (2018) Determination of fungal pathogens of Hypera postica (Gyllenhall) (Coleoptera: Curculionidae): isolation, characterization, and susceptibility. Egypt J Biol Pest Control 2018: 28-39

\section{Submit your manuscript to a SpringerOpen ${ }^{\circ}$ journal and benefit from:}

- Convenient online submission

- Rigorous peer review

- Open access: articles freely available online

High visibility within the field

- Retaining the copyright to your article

Submit your next manuscript at $\boldsymbol{\nabla}$ springeropen.com 